\title{
TPM4/ALK Fusion Gene
}

National Cancer Institute

\section{Source}

National Cancer Institute. TPM4IALK Fusion Gene. NCI Thesaurus. Code C101085.

A fusion gene that results from a chromosomal translocation $\mathrm{t}(1 ; 2)(\mathrm{q} 25 ; \mathrm{p} 23)$ which fuses most of the coding sequence of the TPM4 gene to the last 10 exons of the ALK gene.

This rearrangement is associated with inflammatory myofibroblastic tumor. 